\title{
WIDENING STUDENT ACCESS AND PARTICIPATION IN ALLIED HEALTH SCIENCES: A CRITICAL REFLECTION
}

\author{
B. O. Ige* \\ e-mail: busayo.ige@uct.ac.za
}

\author{
S. L. Amosun* \\ e-mail: seyi.amosun@uct.ac.za
}

\section{N. Hartman*}

e-mail: nadia.hartman@uct.ac.za

*Department of Health Science Education

University of Cape Town

Cape Town, South Africa

\section{ABSTRACT}

Widening of access and participation has become a paramount agenda for Allied Health Sciences education in South Africa. In response to the need the Department of Health and Rehabilitation Sciences, Faculty of Health Sciences, University of Cape Town introduced the Intervention Programme (IP) in 2009 as a strategy for widening of access and participation student. This study reflects on the design and implementation of IP, the complexities of the diversity of students entering the IP, and the implications for curriculum restructuring in the first year of study and beyond. The authors drew on Mezirow's (1990) theory of transformative learning to explain the multifaceted challenges encountered through our own reflection as programme designers and facilitators, as well as organisers of and participants in curricular reviews using data from student interviews, student performance in first and subsequent years of study, and review documentation. The study shows that curriculum restructuring for a diversifying student body across multiple programmes is a complex process with interrelated and influential factors. Our critical reflections revealed the complexities of aligning intentions that are significantly flawed by presuppositions relating needs and outcomes.

Keywords: student diversity; curriculum transformation, intervention programme; transformative learning

\section{INTRODUCTION}

Teaching and learning aimed at developing the kinds of capabilities associated with higher education is presently more complex and demanding. The student body in higher education has changed worldwide, South Africa inclusive. Not only are classes often larger but quite diverse 
in terms of schooling background, student motivation, aspiration, expectation but also levels of familiarity with university culture and language. Changing and redefining higher education from the traditional uni-dimensional 'typical' university student and university experience to multi-dimensional (Kinnear et al. 2008; Horstmanshof and Zimitat 2003). As the recognition of multi student construct continues to gain ground, so does the awareness for the new demands it brings on curriculum and the general university system to deliver equitable education (Smit 2012; Calkins and Seidler 2011; Bush et al. 2010; Muddiman and Frymier 2009). Retention and inclusion of 'non-traditional' or first generation students is acknowledged as essential outcomes (Unterhalter et al. 2007; Watts and Bridges 2006; Gee 2000; Amos and Fischer 1998).

\section{Context of students' learning support}

The curriculum transformation embarked upon at the start of the millennium to widen student access and participation in the Allied Health Sciences in the Faculty of Health Sciences (FHS) at the University of Cape Town (UCT) occurred in the context of multiple challenges facing South African higher education. These include fiscal constraints with attendant demands for cost containment and accountability (Akooje and Nkomo 2007; Wilson-Strydom 2011), trying to understand the implications of Outcomes Based Education (OBE) for students' preparedness for tertiary level studies, academic restructuring, reviewing academic programmes for contextual relevance to the changing national and provincial health system, and consolidation of educational programmes. The implementation of OBE in 1998 was intended to democratise school education (Grades 1-12) and eliminate inequalities in the post-apartheid education system (Jansen 1998; Soudien and Baxen 1997; Todd and Mason 2005; Mouton, Louw and Strydom 2012). It was designed to uplift learners and teachers from previously disadvantaged communities by opening up 'the curriculum to all children and integrate it with their experience' (Mouton, Louw and Strydom 2012).

The Allied Health Sciences in FHS, as part of their commitment to widening access, reviewed admissions criteria that had a long-standing reliance on performance at a certain level in Mathematics, Physical Sciences, Life Sciences and English. This was considered necessary as the dominant perspective at the time (1996-1997) was that few students from educationally under-resourced schools would meet the traditional entry criteria given the low grade 12 pass rates nationally, particularly in Mathematics and Sciences. After close scrutiny of OBE grade 12 subjects, each of the participating professions (Audiology, Occupational Therapy, Physiotherapy, Speech and Language Pathology) agreed to the inclusion of Mathematical Literacy (ML), combined with performance within a certain range on the National Benchmark 
Tests, as additional admission criteria. This decision was a deliberate strategy to attract black students who were largely absent from the student body in the faculty (Bowie and Frith 2006).

Simultaneously, the four Allied Health Sciences professions were reviewing undergraduate curricula for contextual relevance to the changing national and provincial health systems that were being restructured in terms of the Primary Health Care (PHC) Approach; and the Department of Health and Rehabilitation Sciences (DHRS), that housed the four professions, was undergoing academic restructuring as well as consolidation of educational programmes. The curricula of the 4-year undergraduate Allied Health Sciences programmes were substantially restructured to achieve multiple goals. The first was the embedding of critical cross-field outcomes in the curricula to align with the South African Qualifications Authority (SAQA), and subsequently the Higher Education Qualification Framework (HEQF). Secondly, the PHC approach was integrated from first to final year via the creation of multidisciplinary courses in line with primary health care philosophy based on the values of equity and access to 'health for all' (Amosun, Hartman, Van Rensburg et al. 2012). Thirdly, three of the professions introduced early service learning exposure during the foundational phase which is of 2-year duration; and fourthly, improving integration of the basic sciences with profession-specific concepts and topics throughout the foundation phase to strengthen the acquisition of theoretical knowledge. The primary focus of the second phase, the remaining two years, is workplacebased learning under the supervision of clinical educators and supervisors. Intended to foster the skills and attributes required for practice in diverse communities and healthcare facilities, including low-resource settings. The broader process of transforming the curriculum, described above, which commenced in 2004 is on-going. This article aims to contribute to that process.

\section{Supporting student learning}

While the challenge of addressing diversifying student bodies in higher education is a global phenomenon (Warren 2002; Parker, Naylor and Warmington 2005), particular challenges arise in the South African context. In a science-based faculty such as the FHS, changing the demographic profile to be more nationally representative, is to enter into competition with faculties of science, commerce and engineering for the small pool of Grade 12 students who qualify for access to tertiary education in mathematics and science subjects. The University of Cape Town has long recognised that significantly increasing the numbers of historically excluded students from under-resourced schooling backgrounds, especially in the sciencebased disciplines, would require formulation of alternative admissions criteria that had to articulate with curricular structures designed to ensure retention and graduation within a 
reasonable time (Hartman 2012; Wawrzynski, Heck and Remley 2012; Badenhorst and Kapp 2013; Thomas 2010; Van der Westhuizen 2007; Tinto 1975).

Various models of academic support have evolved within the university to address the misalignment between the prior learning experiences of students and assumptions of entry-level courses in standard degree programmes. Based on the experience of Science and Engineering Faculties in South Africa (Jackson, Meyer and Parkinson 2006), assumptions were made that students may not have the necessary level of scientific knowledge, and academic and quantitative literacy skills for success in tertiary education; and that such students would come mostly from under-resourced schools in under-resourced communities. The FHS evolved an Intervention Programme (IP), first adopted in the medical programme in 2002 and first of its kind in the country, was subsequently modified for application in the allied health sciences. IP is a foundational provision programme that extend the regular programmes in the Department by a year. It was designed to empower identified students to actively participate in their learning. Unlike other extended curricular structures at UCT and elsewhere in South Africa, students are not pre-selected into the IP on the basis of alternative admissions scores. Rather the assessment of students' cognitive, conceptual, language and emotional readiness for university-level study is based on performance in the first semester of first-year-level courses. This significant variation in approach was predicated on the need to try and understand the capabilities students brought with them and how these manifested across the first semester. It was also assumed that the broader curriculum restructuring initiatives would promote a learning environment more conducive to students from diverse backgrounds, for example, a shift in focus to health issues affecting communities across the socio-economic spectrum, as well as the rationalisation of the basic sciences to include only topics and concepts relevant and appropriate to the professions.

\section{THEORETICAL FRAMEWORK}

This narrative is situated in a constructionist view of critical reflection. It conceptualises adult reflection as a transformative experience that may lead to changes in personal understanding and behaviour if epistemic assumptions are examined and individuals are willing to move beyond their 'comfort zones' (Mezirow 1990; 1997). We adopt this approach to critically engage with the design and implementation processes of the IP, and to interrogate the outcomes as well as non-academic issues confronting students in our quest to develop a fuller understanding so that we are better equipped to manage and support them.

An additional dimension of the socio-cultural theory underpinning the IP model, is the 
aim to create space for student engagement through evolving a community of practice. This as a socialisation process through which students in IP become increasingly competent members of their new learning environment as they participate and their inputs are recognised and supported through peer and expertise inputs, to enable movement beyond their Zone of Proximal Development (ZPD) and gradually becoming independent and confident of who they are and able to achieve (Lantolf 2000; Vygotsky 1978). The ability to think critically in the discourses of the professions is developed overtime through experience, therefore critical reflection is a key competency advocated in many areas of professional development and practice. It encourages practitioners to gain insight into their own professionalism through their experiences (Brookfield 2009; Leijen, Valtna, Leijen and Pedaste 2012). This led us to begin to ask questions, not only about how IP is shaping student learning but also how student roles and status are shaping IP.

In a review of a similar programme in the United States, which involved both academic staff and administrators, critical self-reflection was found very helpful (Bustillos 2012). The process involved extensive dialogue, and sharing experiences in and out of the classroom. However, Mezirow (1990; 1997) distinguishes between this kind of reflection (on propositions) and that of reflection on premises. The latter requires analysing and challenging the validity of presuppositions, assessing the appropriateness of knowledge and understanding, as well as beliefs given in presenting contexts and monitoring for distortions that may be epistemic or socio-cultural (Figure 1). Larrivee $(2000,293)$ stresses the importance of critical reflection for both educators and students, the absence of which, he argues, may result in their remaining 'trapped in unexamined judgments, interpretations, assumptions, and expectations.' This would require an understanding and acceptance of the review process as being constituted in a rational, critical discourse that connects reflection to action (Mezirow 1990), which is conversant with the transformation imperatives. A review process that foregrounds critical engagement with participants' premises promotes ethical, social and political accountability (Brookfield 2003; Mezirow 1995). Building a Community of Practice (COP) (Lave and Wenger 1991) from these review premises is a valid strategy for curriculum change that has as twin goals greater demographic representativity among graduates who are also fit for purpose. The staff who initiated the process of critical reflection were actively involved in the planning and the implementation of the IP and authored this article. The second author (SLA) was the Head of DHRS when the broader curriculum transformation commenced in 2004, and co-managed the process with $\mathrm{NH}$ as the Director of the Education Development Unit of the FHS. 


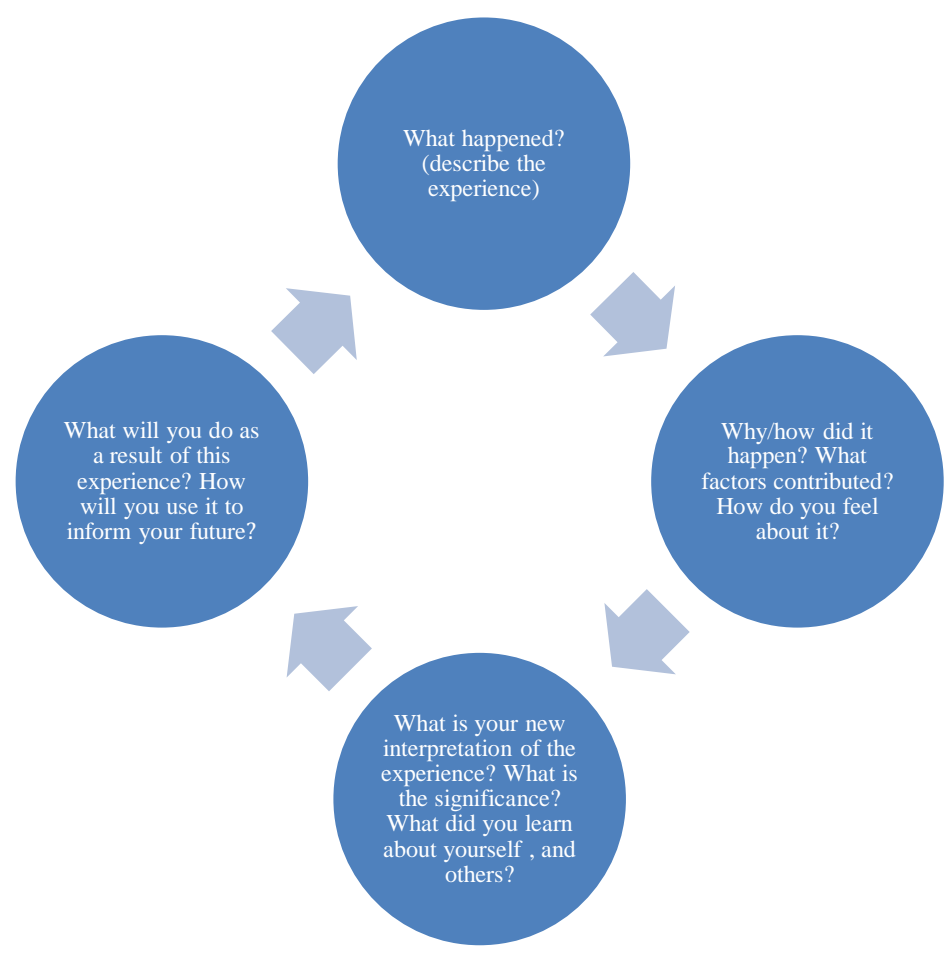

Figure 1: The concept of critical self-reflection (Mezirow 1990)

On completion of the term as Head of Department in 2007, SLA chaired the Undergraduate Education Committee (Shared Learning Committee) of the department, and the partnership with $\mathrm{NH}$ continued for the detailed planning and implementation phases. The first author (BI) was specifically appointed to convene the programme at its inception in 2009, while SLA and NH continued to serve as consultants. In addition, SLA has taken part in facilitating learning among physiotherapy students in the IP. We envisage that critical reflection on the experiences of these three active participants in planning and managing the IP will contribute to strengthening and expanding the existing COP in programmes reviews, and the critical engagement with the broader transformation process as the IP is conceptualised as a 'window' into other parts of the curricula of the four undergraduate programmes. The authors critically reflect on the review processes from the stance of transformative educators committed to building a COP that engages critically with premises for actions that align with the goals of equity in education and health.

\section{OUTCOMES OF CRITICAL REFLECTION}

\section{Design and development of IP model}

The design process was characterized by several stages, namely problem analysis, design and development, and implementation and evaluation (Voogt, Westbroek, Handelzalts, Walraven, 
McKenney, Pieters and De Vries 2011). Thus, the introduction of IP led to re-structuring of the first year courses in all the four undergraduate education programmes, especially in the Sciences. The restructuring process of the one year-long duration courses involved the modularization of the courses into semester modules in order to allow for more time for students' learning (Table 1). It was also assumed that a semester was sufficient time to gauge students' capabilities for first-year level university studies, although there had been considerable debate about whether it could be gauged as early as end of first term (half a semester). A full academic year was considered too wasteful if students needed the kinds of support observed in the science and engineering faculties. Level of academic achievement of the students at the end of the first semester was selected as an indicator of the need for deep academic support of the kind afforded by an extended curriculum. That is, students who attained less than 55 per cent in profession-specific and science service courses, and had not been adversely affected by health, other psycho-social or financial issues would most likely benefit from the more intense academic mediation. These are the students for whom the IP was designed, as a programme meant to provide learning opportunities in profession-specific core concepts, quantitative literacy (QL), basic sciences concepts, and academic literacy (AL).

Table 1: Course structure for main cohort of OBE students

\begin{tabular}{|c|c|c|c|c|c|}
\hline Semester & Modules & Audiology & SLP & OT & PT \\
\hline \multirow{4}{*}{$\begin{array}{l}1^{\text {st }} \\
\text { (January } \\
\text { to June) }\end{array}$} & \multirow{2}{*}{$\begin{array}{l}\text { Service } \\
\text { courses }\end{array}$} & \multicolumn{4}{|c|}{ Psychology 1A } \\
\hline & & \multicolumn{2}{|c|}{ Linguistics Foundation } & \multicolumn{2}{|c|}{ Anatomy/Physiology IA } \\
\hline & \multirow[t]{2}{*}{ Professional } & \multicolumn{2}{|c|}{ Speech and Hearing Sciences } & $\begin{array}{l}\text { Human Occupation } \\
\text { and Development } \\
1 \mathrm{~A}\end{array}$ & $\begin{array}{l}\text { Movement } \\
\text { Science IA }\end{array}$ \\
\hline & & \multicolumn{2}{|c|}{$\begin{array}{l}\text { Human Communication } \\
\text { Development }\end{array}$} & & Biomechanics IA \\
\hline \multirow{4}{*}{$\begin{array}{l}2^{\text {nd }} \\
\text { (July to } \\
\text { December) }\end{array}$} & \multirow{2}{*}{$\begin{array}{l}\text { Service } \\
\text { courses }\end{array}$} & \multicolumn{4}{|c|}{ Psychology 1B } \\
\hline & & $\begin{array}{l}\text { Anatomy for } \\
\text { hearing }\end{array}$ & $\begin{array}{l}\text { Anatomy for } \\
\text { communication } \\
\text { sciences }\end{array}$ & \multicolumn{2}{|c|}{ Anatomy/Physiology IB } \\
\hline & \multirow[t]{2}{*}{ Professional } & \multicolumn{2}{|c|}{ Early Intervention } & $\begin{array}{l}\text { Human Occupation } \\
\text { and Development } \\
\text { 1B }\end{array}$ & $\begin{array}{l}\text { Movement } \\
\text { Science 1B }\end{array}$ \\
\hline & & $\begin{array}{l}\text { Basis of } \\
\text { Hearing and } \\
\text { Balance }\end{array}$ & $\begin{array}{l}\text { Sociolinguistics } \\
\text { Foundation }\end{array}$ & & Biomechanics IB \\
\hline
\end{tabular}

An operating assumption was that the faculty wide student development and support systems that was in place, would identify students' non-academic needs timeously to minimize interference with their studies in the first semester. To provide academic support, each of the programmes was made to timetable tutorials during which the lectures covered is reemphasised. At the end of the first semester, students considered to be 'struggling academically' 
were selected for the IP. The assumptions underlying this division of labour between academic and non-academic support reflect the under-estimation of the competing demands on staffs' time and availability for coordinating academic and non-academic support, where none had existed before.

A further selection into IP could occur at the end of semester 2 of the mainstream programme. Therefore, the $1^{\text {st }}$ semester of the IP would run from July to December of one year (IP I), and designed to revisit at a slower pace and in smaller groups, the learning that took place in the first semester of the mainstream curriculum with particular focus on difficult concepts. The $2^{\text {nd }}$ semester of IP would run from January to June of the following year (IP II), and designed to prepare the students for a return into the mainstream, by introducing new material to give them the opportunity to experience some of the key concepts that they will encounter in the mainstream. The courses offered in the programme are presented in Table 2. Notable, 'Entry-level Psychology for Health and Rehabilitation Sciences' was central course for all IP students, and was designed to facilitate and enhance skills in academic literacy, among others. It was assumed that this model of IP, conceptualised as 'looking back and looking forward', would enhance students' participation while learning in a community of practice (Wegner 1998; Vygotsky 1978). Successful students would exit IP II in July of the following year to return to the mainstream of first year.

Table 2: Course structure for IP students

\begin{tabular}{|c|c|c|c|c|c|}
\hline Semester & Modules & Audiology & SLP & OT & PT \\
\hline \multirow{4}{*}{$\begin{array}{l}1^{\text {st }} \\
\text { (July to } \\
\text { December) }\end{array}$} & \multirow{2}{*}{$\begin{array}{l}\text { Service } \\
\text { courses }\end{array}$} & \multicolumn{4}{|c|}{ Preparation for entry-level Psychology Part 1} \\
\hline & & \multicolumn{2}{|c|}{ Linguistics Foundation } & \multicolumn{2}{|c|}{ Fundamentals of Anatomy/Physiology IA } \\
\hline & \multirow[t]{2}{*}{ Professional } & \multicolumn{2}{|c|}{$\begin{array}{l}\text { Fundamentals of Speech and } \\
\text { Hearing Sciences }\end{array}$} & $\begin{array}{l}\text { Fundamentals of } \\
\text { Human Occupation } \\
\text { and Development } \\
1 \mathrm{~A}\end{array}$ & $\begin{array}{l}\text { Fundamentals of } \\
\text { Movement } \\
\text { Science and } \\
\text { Applied PT IA }\end{array}$ \\
\hline & & \multicolumn{2}{|c|}{$\begin{array}{l}\text { Foundational concepts in Human } \\
\text { Communication Development }\end{array}$} & & $\begin{array}{l}\text { Fundamentals of } \\
\text { Biomechanics IA }\end{array}$ \\
\hline \multirow{5}{*}{$\begin{array}{l}2^{\text {nd }} \\
\text { (January } \\
\text { to June) }\end{array}$} & \multirow{3}{*}{$\begin{array}{l}\text { Service } \\
\text { courses }\end{array}$} & \multicolumn{4}{|c|}{ Preparation for entry-level Psychology Part 2} \\
\hline & & \multicolumn{2}{|c|}{$\begin{array}{l}\text { Anatomy for Communication } \\
\text { Sciences }\end{array}$} & \multicolumn{2}{|c|}{ Fundamentals of Anatomy/Physiology IB } \\
\hline & & & $\begin{array}{l}\text { Sociolinguistics } \\
\text { Foundation }\end{array}$ & & $\begin{array}{l}\text { Fundamentals of } \\
\text { Biomechanics IB }\end{array}$ \\
\hline & \multirow[t]{2}{*}{ Professional } & \multicolumn{2}{|c|}{$\begin{array}{l}\text { Foundational concepts in Early } \\
\text { Intervention }\end{array}$} & $\begin{array}{l}\text { Fundamentals of } \\
\text { Human Occupation } \\
\text { and Development } \\
\text { 1B }\end{array}$ & $\begin{array}{l}\text { Fundamentals of } \\
\text { Movement } \\
\text { Science and } \\
\text { Applied PT IB }\end{array}$ \\
\hline & & $\begin{array}{l}\text { Basis of } \\
\text { Hearing and } \\
\text { Balance }\end{array}$ & & & \\
\hline
\end{tabular}




\section{Programme implementation and student realities}

The programme turned out to be more complex than the MBChB IP that it mirrors. In the first year of its implementation, we were forced to re-engage with some questions that were raised during the identification and analysis of possible learning challenges, such as 'who are the students?' Although the programme was not new to the FHS, it was new to staff and students in DHRS. Once students were placed in the programme we had to deal with the reality on ground. The complexity of students' diversity and challenges became apparent very quickly during this period.

\section{Diversity of students in IP}

A fairly high proportion (19.6\%) of the mainstream ended up in the first cohort of IP. The first issue that emerged related to the complexity of the identity of the students in the IP. Based on the admission policy of the university, the course design team assumed that students from the classified 'Black' African and 'Coloured' population groups would need additional academic support in the undergraduate programmes, in contrast to the traditional 'white' intake from wellresourced schools, high grade 12 scores and low failure rates (Amosun et al. 2012). However, a number of the students placed in the programme, as a result of failing first semester, did not fit into these criteria. There were students across all race groups, socioeconomic and schooling backgrounds (Table 3). Consequently, the construct of an 'educationally disadvantaged' student was challenged as the programme enrolled students from former model C schools and private schools. This resulted in more than the anticipated number of students being eligible for IP, and the cohorts becoming less homogeneous. This created a complex teaching and learning environment made up of a mixture of perceived academically 'strong' and 'weak' students. This phenomenon repeated itself in the subsequent years. Due to the impacts of these developments on the programme (Smit 2012), the design and implementation team unanimously concluded that there was a need to first identify the characteristics of $1^{\text {st }}$ year students who ended up in IP. Thus, the development of an 'at-risk list' database of $1^{\text {st }}$ year students was initiated. The risk list was used to capture individual IP student details comprising of demographic data, pre-admission assessment scores (matric scores, placement or National Bench Mark for numeracy and literacy tests), first semester mainstream result, as well as qualitative information on individual students where available. This was used for tracking, monitoring and mentoring students in the programme.

A critical reflection for the authors is the continued difficulty in identifying and coordinating academic and non-academic support needs to recruit only those students needing 
deep academic support. Even the creation of an 'at-risk list' did not significantly reduce the number of students ending up on IP due to failing the first semester. Further, the 'at-risk' list database was not able to offer indications as to why students from educationally advantaged, and socio-economically more privileged backgrounds ended up failing the first semester. It seems to suggest that supporters of a one-year assessment period had valid assumptions and the pragmatic compromise of placement after a single semester is flawed. However, there had been instances when students who 'scraped through' first year began to struggle academically in the senior years, which led to academic exclusion in some cases.

Table 3: Profile of IP students (2009-2013)

\begin{tabular}{|l|l|l|l|l|l|l|l|l|l|}
\hline \multirow{2}{*}{ Cohort } & \multicolumn{4}{|c|}{ No of students per programme } & \multicolumn{2}{c|}{ Total } & \multicolumn{4}{c|}{ Population groups of students in IP } \\
\cline { 2 - 10 } & Audio & OT & PT & SLP & & Black & Coloured & Indian/Asian & White \\
\hline 2009 & $5 / 23$ & $6 / 57$ & $22 / 73$ & $1 / 30$ & 34 & 22 & 10 & 2 & 0 \\
\hline 2010 & $2 / 23$ & $8 / 56$ & $19 / 79$ & $2 / 30$ & 31 & 13 & 13 & 1 & 3 \\
\hline 2011 & $4 / 28$ & $10 / 65$ & $9 / 77$ & $4 / 37$ & 27 & 13 & 11 & 1 & 2 \\
\hline 2012 & $5 / 39$ & $7 / 62$ & $9 / 65$ & $2 / 45$ & 23 & 17 & 5 & 1 & 0 \\
\hline 2013 & $6 / 31$ & $6 / 59$ & $13 / 63$ & $1 / 47$ & 26 & 13 & 9 & 1 & 2 \\
\hline
\end{tabular}

Audio -Audiology; OT - Occupational Therapy; PT - Physiotherapy; SLP - Speech and Language Pathology $x / y$ : $x=$ number of students in IP; $y=$ number of students in main stream of $1^{\text {st }}$ year

\section{Choice and relevance of degree programme}

The first choice of study for many of the $1^{\text {st }}$ year students was medicine, which was not limited to physiotherapy students but included Audiology, Occupational therapy and Speech-Language Pathology students. However, they were now registered for alternate courses, and this impacted on their level of motivation and commitment as such students struggled with the acceptance of a second choice programme. The resultant demotivation was further complicated as affected students sought to establish the relevance of courses required in the new career path. The relevance of services courses for the different degrees was constantly questioned, as well as relevance of topics covered in the courses. These developments presented the potential to derail the learning process and student progress unless they were adequately addressed (Kember, Ho and Hong 2008; Lave and Wenger 1991). It became clear that there were a number of students in this category. Being demotivated, they performed poorly enough to end up in IP. In some of these cases, aptitude was not the problem but attitude. As it emerged in the students' own reflection of 'what went wrong' in the first semester of mainstream curriculum, the commitment and motivation to persist was lacking. In addition, students cited heavy workload and 'fast pace' of teaching and learning as major factors contributing to their poor performance in the first semester. 


\section{Students' unpreparedness for IP}

Nearly all the students who came into the progamme were shocked, with a sense of disappointment and resentment, when they were informed about their placement in IP. In anticipation of these emotional challenges, based on the experience with medical students (Sikakana 2010), the students were addressed by invited senior academic staff in DHRS, who admonished the students to see the IP as a support programme in their interest rather than an indicator of their failure. In addition, ex-IP students from the MBChB programme were invited to share their personal experiences, initiating a programme to programme interaction, specifically between students. However, the students' reactions indicated a strong dissatisfaction with their new student status, but the interaction with MBChB ex-IP students may have tempered their disappointment. There was a strong resistance from the students, which ultimately affected their participation in teaching and learning activities. This created an unhealthy learning environment as both students and facilitators were frustrated, and the IP was rendered handicapped for a period.

It was therefore necessary to immediately address the poor understanding the students had about IP as the situation was leading to poor motivation to learn, confusion and conflict (Wilson 2004; House 2000). By the end of the second week in IP, the academic timetable was restructured to create platforms initially tagged as 'Debriefing Session', but later renamed 'Personal Development Workshop', where the emotional and psychological needs of the students were addressed. This was in line with the perceptions that before academic problems could be addressed, the emotional or psychosocial issues must be attended to (Petersen, Louw and Dumont 2009). We liaised with the Student Wellness Centre of the university, and organized weekly debriefing sessions facilitated by a psychologist. These sessions were timetabled for the rest of the first semester in IP, and the impact was evident within weeks as students gradually began to respond more positively.

This experience highlighted the importance of student disposition for the successful implementation of the support initiatives for the transition of students from high school education to tertiary education (Struyven, Dochy and Janssens 2005). Students' motivation, which is based on students' perceptions, is seen as an essential tool that drives learning. Having to address the unanticipated reactions of the students was a recognition of the significant role of student participation in transformative processes. It became clear that proper dialogue with students is essential for any changes that involves them directly. This recognition of the role of students strengthens and further legitimize their position as members of the academic communities of practice. It becomes critical therefore to ensure that all first-year students have 
a good understanding of IP and the benefit derived from their participation in the programme.

\section{Fitness of model and professional programme diversity}

The model of the programme impacted the students as well as the faculty. It was the intention of the designers to pilot this model of IP because of its success in the undergraduate medical programme in the faculty (Sikakana 2010). However, it later became obvious that the model did not fit the needs of all the four undergraduate allied health sciences programmes. One major difference between the IP programmes in medicine and the allied health sciences is that the former offers intervention for one professional programme (MBChB) whereas the latter offers intervention for four different professional programmes. Divergent curricular designs of four professional programmes resulted in complexity and specific challenges that were absent from the MBChB IP. For instance, the semesterised courses in two out of the four disciplines in the Health and Rehabilitation Sciences IP (OT, PT) were strongly linked, giving the opportunity to implement the model philosophy of 'looking back and looking forward'. What this meant was that Audiology and SLP students wrote examination in the first semester of IP and others only at the end of the second semester. This resulted in major conflict in term of the model philosophy. Attempts to harmonise the philosophy of the model met with strong resistance which was never anticipated during the planning phase.

The planning phase required that apart from repeating the courses failed, students would also repeat courses where the final mark obtained was less than 55 per cent. However, in the first year of implementation, not all the programmes agreed to implement the plan. One of the four programmes insisted and required their students to repeat all courses irrespective of their previous marks. This resulted in some tension between the designers of IP who conceived the model and its application, and the Heads of the academic programmes. Due to the close articulation of IP courses with the mainstream curriculum, the Heads of the academic programmes 'dictated' the rules for their respective IP related courses. Unfortunately, all these issues were not successfully negotiated prior to implementation of IP. Student protested by refusing to participate in class discussion, and disrupted the classes to ensure that the few students that were willing to engage could not do so. This contributed to the unpreparedness of students to engage with learning activities in the program. The 'Debriefing Session’ previously described helped to an extent to bring students back into class discussions.

The level of resistance encountered from the different participating programmes to 'tamper' with the structures of their programmes was beyond what was anticipated. Indirectly, the design and implementation team was perceived to be 'outsiders' whose function was limited 
to an advisory role. On reflection, and given the depth of resistance to certain key design features of the IP model, the design team should have motivated to the Faculty Executive that we delay implementation of the IP, and devote more time to obtaining the buy-in of key roleplayers, and work on design modifications if necessary. However, there was considerable pressure to stick to the schedule for implementation, given that the changed admissions criteria had already been endorsed unanimously by Faculty Board for implementation in 2009.

Most of the students who failed only one course in the mainstream were therefore resentful of their placement in the programme. The implemented model also had financial implications for students not on bursaries or financial aid. They had to pay for the 'repeat' courses whereas the bursars or financial aid schemes carried the costs for their students. This added to the frustration of the students who were either self-sponsored or sponsored by parents and guardians. The students resisted their stay in the programme for a semester or more, and were highly demotivated for most part of their stay. Intuitively these students were unable to connect the purpose of IP to their immediate learning difficulties, for the reasons Wilson and Sperber (1985) referred to as cost and benefit effect. In other words, because the students perceived that the cost of being in IP outweighed the benefit, their level of motivation dropped significantly, leaving students trapped and unable to fully participate and engage with teaching and learning. The funding practicalities for IP also impacted the faculty. The low headcount of students (Table 3) and the small group-teaching model incurred additional costs to the faculty. The IP staff consisted of eight part-time lecturers, one full time course coordinator and an administrator to a small number of students. On reflection, the design team had not lobbied sufficiently for existing full-time, permanent staff in the department to contribute to teaching in IP. It was generally perceived that IP was a 'stand-alone' programme that should have its own teaching staff and administrator. In addition, it was perceived that the simultaneous broader curriculum transformation that was underway had placed heavy demands on the mainstream academic and administrative staff. Perhaps a delay in the process by calling for strategic prioritising of resource allocation amongst the leadership of the DHRS together with Faculty Executive might have yielded a more affordable staffing model, and down the line, yielded greater efficiencies with lower staff turn-overs.

The outcomes from the 'Personal Development Workshops' indicated that the factors that contributed to enrolment of students in IP were not limited to issues about the programme. For most of the students, a combination of factors led to their enrollment, which the planning and implementation team did not anticipate. It was therefore necessary to understand and engage the various intersections of the emerging factors to facilitate the process of addressing them. 
The personal development workshops highlighted some of the challenges the students' encountered while still in the mainstream cohort of the first year, which could have impacted their academic performance. These challenges included -

\section{Mis-matched expectations between students and academics}

Students' expectations rarely matched their subsequent experiences in the first semester of study. For instance, the pace and volume of work was not envisaged. While prior curricula transformation took place in anticipation of the diversity in the class, what transpired at micro level mostly reflected the expectations of the lecturers. So while the students expected that learning would be facilitated at their ZPD, there were assumptions that the students would cope with the pace of learning and workload dictated by the academics. Other common mismatched expectations which resonate with research reported on first year students' expectations included university expectation of independent learning and limited access to staff for consultations (Crisp, Palmer, Turnbull, Nettelbeck, Ward, LeCouteur, Sarris, Strelan and Schneider 2009; Brinkworth, McCann, Matthews and Nordstrom 2009). Although the programme acknowledged the varieties in the schooling and socioeconomic background of the students, which was used to prepare and put in place necessary supports for learning challenges that may present itself, what was missing was a clear engagement with students’ perceived expectations and the implication of this in the processes.

\section{Students' needs: Academic and non-academic}

Academic and non-academic factors also impacted students' learning from when they were in the mainstream. A study skills survey was designed and administered among IP students with the hope of uncovering study skills issues that could be impeding student learning. Series of diagnostic test and quizzes were also used to identify areas of conceptual and language difficulties in the different courses offered in IP. The academic related factors identified included poor academic literacy skills, poor understanding of concepts in the professional and service courses, as well as a lack of study skills required to succeed in higher education. These were more evident among students from rural school backgrounds, who struggled with understanding science-related concepts, which was further compounded with poor study skills. The complexity of diversity of need increased with what emerged as different levels of literacy and numeracy skill in the same classroom.

Non-academic needs of the students included poor self-regulation in engaging with their academic responsibilities in the university. This led to a ripple effect of how they handled their 
own learning. Unlike high school, students were expected to take responsibility for their learning as a student-centred approach was promoted, without close monitoring of the students. In addition, there were issues relating to financial needs, accommodation, and social and family lives. Affected students were assisted by the Student Support Portfolio of the department to liaise with the Students' Housing and the Wellness Centre of the university, for appropriate support.

\section{Reflections on reviews and evaluations}

Reviews formed an integral part of IP curriculum development process (Voogt et al. 2011). The experiences during the implementation phase prompted the design team to unanimously conclude that there was a need for periodic reviews of the programme, which led to the review timelines in Table 4. The first review took place at the end of the first semester of IP in December 2009, with a primary goal to evaluate and assess the programme both from the perspectives of the students and the facilitators (Bustillos 2012). The review paid specific attention to factors that contributed to students' disconnection to learning, including agitation over 'repeating' courses passed in the first semester of mainstream, as well as gaps in academic literacy. While the model remained unchanged because it was still in its first year of implementation, some amendments were recommended and implemented where possible.

Two broad recommendations emerged from this review data, which were implemented. The first related to the explicit integration of academic literacy into all IP courses and quantitative literacy where appropriate. This would clearly establish differentiated learning outcomes for the IP and regular courses. The second recommendation pertained to establishing stronger collaboration between IP and regular courses' teaching staff in the interest of students returning from IP to the regular courses. It was anticipated that the closer working relations would foster adoption of teaching strategies identified as successful in IP into the regular courses, thereby contributing to reflection and engagement on best educational practice (Amos and Fischer 1998). The impact of this initial review was also visible when looking at the disposition and performance of the second cohort of students compared with their predecessors. In the process, academic literacy in reading and writing, as well as quantitative literacy were reassessed especially with growing evidence that suggested that a number of the students struggled with academic and quantitative literacies and study skills beyond IP courses. It was recommended that academic literacy be integrated into psychology, given that this is a course offered to all the students across all the four programmes. Quantitative literacy was introduced for students in Audiology, Physiotherapy, and Speech and Language Pathology. 
Table 4: IP Reviews and Evaluation (2009-2013)

\begin{tabular}{|c|c|c|c|c|c|c|c|c|c|c|c|c|c|c|}
\hline & 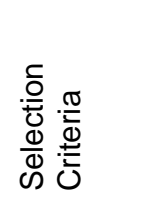 & 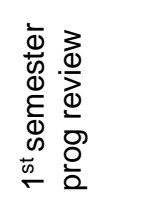 & 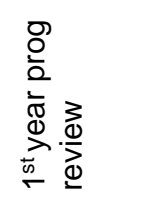 & 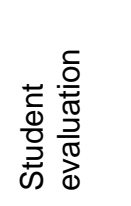 & 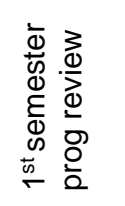 & 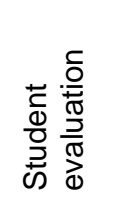 & 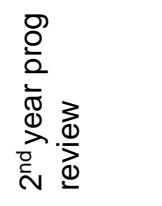 & 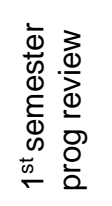 & 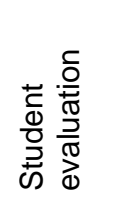 & 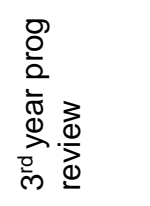 & 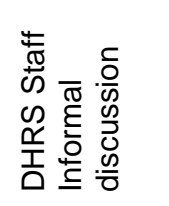 & 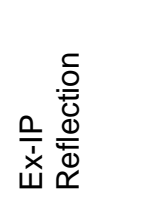 & 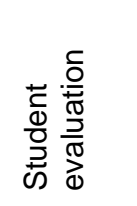 & 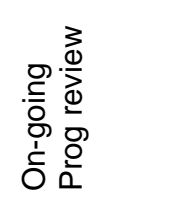 \\
\hline $\begin{array}{l}\text { Time } \\
\text { line }\end{array}$ & Sept 2009 & Dec 2009 & July 2010 & $\begin{array}{l}\text { July } \\
2010\end{array}$ & $\begin{array}{l}\text { Dec } \\
2010\end{array}$ & $\begin{array}{l}\text { June } \\
2011\end{array}$ & July 2011 & $\begin{array}{l}\text { Dec } \\
2011\end{array}$ & $\begin{array}{l}\text { June } \\
2012\end{array}$ & July 2012 & Oct 2012 & $\begin{array}{l}\text { March } \\
2013\end{array}$ & $\begin{array}{l}\text { June } \\
2013\end{array}$ & April 2013 \\
\hline Level & Faculty & $\begin{array}{l}\text { Faculty } \\
\text { and inter- } \\
\text { depart- } \\
\text { mental }\end{array}$ & $\begin{array}{l}\text { Faculty } \\
\text { and inter- } \\
\text { depart- } \\
\text { mental }\end{array}$ & Prog & Prog & Prog & Dept & Prog & Prog & Faculty & Dept & Dept & Prog & $\begin{array}{l}\text { University } \\
\text { level }\end{array}$ \\
\hline COP & $\begin{array}{l}\text { HOD, } \\
\text { HoDivs, } \\
\text { EDU, } \\
\text { CRMT, } \\
\text { MBChB IP } \\
\text { team and } \\
\text { staff, } \\
\text { Health and } \\
\text { Rehab IP } \\
\text { team and } \\
\text { staff }\end{array}$ & $\begin{array}{l}\text { HOD } \\
\text { CRMT, } \\
\text { EDU, } \\
\text { HoDivs, } \\
1^{\text {st }} \text { year } \\
\text { conve- } \\
\text { ners, } \\
\text { IP team } \\
\text { and Staff }\end{array}$ & $\begin{array}{l}\text { HOD, } \\
\text { HoDivs, } \\
\text { EDU, } \\
\text { MBChB } \\
\text { team, } \\
\text { CRMT, IP } \\
\text { team and } \\
\text { staff }\end{array}$ & $\begin{array}{l}\text { IP } \\
\text { students }\end{array}$ & $\begin{array}{l}\text { IP staff, } \\
\text { EDU } \\
\text { rep }\end{array}$ & $\begin{array}{l}\text { IP } \\
\text { students }\end{array}$ & $\begin{array}{l}\text { HoDivs, } \\
1^{\text {st }} \text { year } \\
\text { conve- } \\
\text { ners, } 1^{\text {styr, }} \\
\text { lecturers, } \\
\text { IP team } \\
\text { and staff, } \\
\text { EDU }\end{array}$ & $\begin{array}{l}\text { IP staff } \\
\text { EDU } \\
\text { rep }\end{array}$ & $\begin{array}{l}\text { IP } \\
\text { students }\end{array}$ & $\begin{array}{l}\text { CHED, } \\
\text { Deputy } \\
\text { Dean, } \\
\text { HOD, } \\
\text { HoDivs, } \\
\text { EDU, } \\
\text { Student } \\
\text { support, } \\
1^{\text {st } y e a r ~} \\
\text { convener, } \\
\text { IP team } \\
\text { and staff }\end{array}$ & $\begin{array}{l}\text { HOD, } \\
\text { HoDivs, } 1^{\text {st }} \\
\text { year } \\
\text { conveners, } \\
2^{\text {nd }} \text { year } \\
\text { conveners, } \\
\text { EDU, IP } \\
\text { team }\end{array}$ & $\begin{array}{l}\text { Ex-IP } \\
\text { students } \\
\text { from } 1^{\text {st }} \text { to } \\
4^{\text {th }} \text { years, } \\
\text { HOD, IP } \\
\text { team and } \\
\text { convener }\end{array}$ & $\begin{array}{l}\mathrm{IP} \\
\text { students }\end{array}$ & $\begin{array}{l}\text { Deputy } \\
\text { Dean, CILT, } \\
\text { Faculty } \\
\text { Admission } \\
\text { committee, } \\
\text { EDU, HOD, } \\
\text { Dept } \\
\text { Under- } \\
\text { graduate } \\
\text { portfolio } \\
\text { chair, IP } \\
\text { team and } \\
\text { convener }\end{array}$ \\
\hline
\end{tabular}

COP - Community of Practice: Faculty; Inter-departmental level; Intra-departmental level

P team - Design team

CRMT - Curriculum Review Management Team

EDU - Education Development Unit

HoDivs - Heads of Divisions (Audiology, Speech-Language Pathology, Occupational Therapy and Physiotherapy)

CILT - Centre for Innovation in Learning and Teaching 
The first review process has indicated that this single model did not fit the needs of the four undergraduate programmes. This remains a challenge that continues to surface in subsequent reviews. Nevertheless, by tapping into the outcome of the first review, we used the opportunity to create the platform for broader engagement of mainstream colleagues across the divisions and key members of faculties in IP. On this platform, we were able to bring the issues that have emerged in IP to the mainstream, including the issues that surfaced while the students were still in the mainstream. The forum of the platform provided opportunity to jointly address these issues as general students' issues, rather than IP students' issues. We subsequently used this base to start broadening our community of practice in teaching and learning beyond IP. Indirectly, it was possible to influence everyone involved to begin to reflect on their own teaching and learning activities. However, the level of reflection is likely to have remained at the propositional rather than epistemic levels as advocated by Mezirow, given the newness of the process and the short time frame for the review activities. In addition, lecturers in the mainstream were being sensitized to the fact that the period of transition from high school to university was not limited to the week of orientation of new students after registration (Kang'ethe and Muhuro 2014). Finally, the review process highlighted the need for students to be actively engaged in the process to ensure their full participation (Struyven et al. 2005). The involvement of students would help to reveal the complexities, richness, tensions, contradictions and transformations involved in multicultural, multilingual and multiracial academic context like ours. On critical self-reflection, we did not follow-up with the IP staff who participated in the review process nor lecturers in the mainstream, as a formal evaluation process, to ascertain whether any change in perspective had occurred, and what the nature of the change was, for each of the staff members. Due to resource constraints, we were reliant upon end-of-sessions feedback in which staff reported how helpful and stimulating sessions had been.

Another major development that triggered the review and evaluation process in December 2009 was the high failure rate in a number of courses in 2009 among the first cohort of OBE students. This, in addition to the mismatch in expectations of students and academic staff, as well as the academic and non-academic needs of students, prompted the IP design and implementation team to motivate for revisiting the 'restructured' first year of study. The outcomes of the analyses of the assessments of students in the mainstream revealed that these students also needed additional academic support. As the demand for more complex cognitive processing emerged to integrate and apply the biomedical and psycho-social sciences across different settings in all years of training, including clinical settings in the senior years. To address this, an inter-departmental review of main stream courses was initiated. This was a process that involved multiple disciplines engaged in cross-disciplinary review of all curricular 
aspects. This was extended to include the review of the basic structure for the remaining years of study ( $2^{\text {nd }}$ to $4^{\text {th }}$ years) which were left intact during the design and development stage of the IP. This process led to other faculty-led reviews in 2010 and 2012, as well as departmental and programme reviews in 2011, 2012, and 2013, which all focused on main stream courses across the years of study, as well as the IP.

Significant outcomes from these reviews were the re-structuring of the first two years of the mainstream programmes to achieve more realistic learning outcomes per year level, taking into account the cognitive and conceptual levels students were bringing to the first and second years of study. For example, the review of the first two years in Physiotherapy led to the redesign of Biomechanics to spread over the first 2 years instead of one year. This restructuring provided some clarity on the horizontal and vertical integration and articulation between courses in each discipline, as well as a closer working relationship between all teaching staff, including the IP. It was evident that some of these staffs' presuppositions regarding the role of the lecturer were shifting from deliverer of information and resources for learning, to mediating both cognitive and conceptual access via deliberate course design that seeks to align learning outcomes with teaching and learning activities as well as assessment (Biggs 1996). In addition, some staff were forced to confront their presuppositions at an epistemic level, for example, culture-biased referents in case-based teaching and assessment disadvantaged students who were unfamiliar with the cultural referents. When acknowledged and culturally sensitive cases were re-written, students who had been nonplussed performed better. These reviews would serve as an acknowledgement of poor course design and not deficiency on the part of the student (Smit 2012).

The experience of restructuring across the two year-levels led the authors of this narrative to motivate to the faculty leadership for a vertically spiraling academic development intervention in the first, second, and third years of study, referred to as 'Augmented Support'. The review of the 'restructured' first year led to among others, the development and piloting of augmented support in the first semester of 2014. However, the challenge to implement vertically-spiraling augmented support will require additional funding for staffing assistance, as this mode of support does not qualify for funding from the Department of Higher Education's Foundational Grant which funds the IP, despite changes made to the funding formula recently. In the new climate of austerity, appropriate and relevant mediation for students accessing increasingly complex concepts and practices of the disciplines and professions will be in severe competition with other demands on the university budget, as well as the increasing pressure for departments to generate third stream income and produce more publications as a researchintensive university.

There was a major faculty level review of the IP after the first three years of 
implementation. The review indicated that the service courses were particularly problematic for Allied Health Science students, which in turn led to reviews of those courses. In regard to service courses offered outside of the Faculty of Health Sciences (for example Psychology), attempts to negotiate courses specifically relevant to health sciences have been unsuccessful as these are seen as non-economically viable. However, additional tutorial support has been made available. In regard to service courses within the faculty, it was recommended that the second and third year service courses be restructured to cater directly to the learning and professional needs of the allied health sciences. For example, Clinical Sciences was spread over the $2^{\text {nd }}$ and $3^{\text {rd }}$ years instead of only in the $3^{\text {rd }}$ year, to cater for the needs of students in Occupational Therapy and Physiotherapy. Little or no resistance was experienced in this process.

The outcomes have contributed to expanding the pool of academic staff participants, and greater understanding of the complexities entailed in curriculum restructuring for widening access and graduating students competent to practice in a restructured health system. The staff who drove this scale of educational change were responsive to national higher education policy imperatives in South Africa, as well as a post-apartheid restructuring of the national health system to create systemic access to and equity in health care delivery via the PHC approach (Amosun et al. 2012).

Preliminary data from IP indicated that of the 34 students in the first cohort of IP (Table 3), two students deregistered to register in another faculty, 7 students were excluded at the end of IP, and the remaining 25 students returned to the mainstream programmes. Ten of the 12 students who made it to the final year in 2013 successfully completed the programmes and graduated. Similarly, for the 31 students in the second cohort of IP, 3 students deregistered to register in another faculty, 2 students were excluded at the end of IP, and the remaining 26 students returned to the mainstream programmes. Fifteen of the 16 students who made it to the final year in 2014 graduated at the end of the year. The detailed experiences of the students in the IP and mainstream programmes will be described in future manuscripts as part of the ongoing review of the curriculum transformation process in the DHRS.

After more than ten years of the curriculum transformation process, there is evidence of 'transformation fatigue' especially among the longer-serving academic staff. Identifying strategies for inclusivity of newly-appointed academic staff, as well as continued engagement with the array of challenges that surface as implementation occurs, has proven essential. Gradually this is translating into a recognition that staff need professional development in educational practice. The multiple IP course and programme reviews undertaken facilitated continued engagement as well as enabling reflection among a range of participants, the individual participating member of staff directly or indirectly started his/her own journey of transformation (Mezirow 1997). As the process offered transformational opportunity to 
interface with all staff members, most of who were not directly involved in the planning stage. However, the experiences or realities described in the implementation of the IP serve as pointers to the complexities encountered in our attempt to build a COP of transformative educators.

Further reflection on the IP review processes has illuminated power differentials. For example, it has been easier to address activities that would enhance student learning at the coalface of the classroom and community site than overall student development. Similarly, it was easier to engage teaching colleagues in the attempt to widen the COP, than it has been to engage departmental and faculty leadership on priorities in resource allocation. Overall, the IP review indicated that curriculum restructuring for a diversifying student body across multiple programmes is significantly more complex an undertaking than for a single programme with multiple courses as was the case in the undergraduate medical programme in the same university (Hartman et al. 2012; Sikakana 2010).

\section{IMPLICATIONS FOR HIGHER EDUCATION}

The outcomes of this study present with possible implications for higher education. It is important to note that first year experience is not a homogeneous experience but diverse and multifaceted, particularly in context of academically and demographically diverse student population. The experiences are not only as diverse as the backgrounds and by cohorts, but are continually evolving and changing during the very first year of study. As we have reported, nearly every first year student is confronted with one or more challenges that come from mismatched expectations, and social and personal issues in their first semester of study. For example, for some students, what began with culture shock in term of expectations, such as workload, literacy skills etc. was replaced or/and compounded with non-academic issues, such as finding accommodation close to or on campus. These experiences may completely derail student learning, and highlight the fact that first year experience is a critical foundation for students' long-term academic success in higher education.

To ensure student success, the integral role of first year experience needs to be acknowledged as pertinent to student persistence and success in higher education. This underscores the importance of having a comprehensive support system for first year students. Without appropriate academic and non-academic support to help unpack and navigate the new learning environment, as well as expectations and opportunities, some students, especially those coming underprepared and underrepresented would feel lost. These conclusions from our reflections concur with findings in USA, Australia and United Kingdom on the first-year experience. Of relevance to our context is the Australian findings regarding 'equity students' that need comprehensive support (Gunston and Olcker 2015; Yorke and Longden 2008; Krause, Hartley, James and McInnis 2005; McInnis 2001). Essentially, foundational or academic 
support programmes like IP should embrace the multifaceted nature of first year experience in order to address first year challenges holistically in all its diversity. In planning such programmes, it is essential that diversity-experience be a core tool in the design and implementation of the programme. Different approaches should be openly discussed and explored, as model fitness is paramount to the success of such programme.

If adequately explored, the data on first year students' experience can serve as a great resource for dealing with issues relating to students learning experiences beyond first year, and foster persistence and success in the senior years. Our data on the lived realities of students combined with student performance data, pointed to the need for curricular restructuring beyond the IP, and was subsequently drawn on to inform support initiatives introduced in the senior years. In other words, IP became a 'window' of opportunity into deeper understanding of students' issues in its many forms beyond first year in the Faculty. As a strategy for widening access, it revealed the complexities of aligning intention with outcome that are significantly flawed by presupposed knowledge of the challenge. It created new avenues and opportunities for the department as a whole to engage with curriculum transformation at a broader level, e.g. revisiting curriculum alignment between first and second year courses, identification of courses that may impede progress in third and fourth year. These outcomes indicate that a greater focus on institutional research within academic programmes, faculties and university-wide (as in the Australian literature cited) could enable higher education institutions to become more responsive, timeously, to the needs of diversifying student entrants transitioning from secondary to higher education. Institutional research combined with the existing body of research on academic development programmes and academic literacies in South Africa spanning two decades, provide a rich data set for research aiming to understand students' experience, both academic and social (Boughey and McKenna 2016; Luckett 2010; McKenna 2004; De Kadt and Mathonsi 2003; Angelil-Carter 1998). The student protests of the last two years have foregrounded the inequalities within the South African Higher Education student body and points to the need for research that goes beyond understanding diversity. Research paradigms that uncover how inequality is perpetuated are required. Our experience of using analysis of student performance data across academic programmes to identify problems in course design, particularly the absence of sensitivity to cultural referents in class and assessment activities, point to the value of Mezirow's theory of transformation that requires teachers to critically reflect on their epistemic assumptions.

Our study also highlights how reviews of a support programme can become a vehicle for widening community of practice and support for transformational agenda among mainstream/traditional staff in higher education. The strategy of undertaking multiple interdepartmental and faculty reviews, facilitated a vigorous engagement and discussion that 
contributes to shifting the blame from 'inadequately' prepared students (Smit 2012) to what is considered as good educational practice, and what 'fit for purpose' graduates require in a changing health system. The outcomes have contributed to expanding the pool of academic staff participants, greater understanding of the complexities entailed in curriculum restructuring for widening access, and graduating students competent to practice in a restructured health system. However, it must be stressed here that reflection based upon course and programme reviews can potentially introduce unintended constraints on a transformation process. For example, over-reliance on trends in student performance data without accompanying analyses of course and programme alignment with the philosophic and practice shifts intended in the curriculum change may result in skewed problem interpretation and solution-generation. For instance, students' lack of preparedness or commitment to work could mistakenly be identified as the source of the problem, which resonated with a deficit thinking model (Smit 2012), whereas students' confusion related to a hidden curriculum resulting from a divergence of education practice from intended philosophy and policy may be overlooked.

\section{CONCLUSION}

Our main aim in this study was to identify and critically reflect on factors that may have facilitated or hindered the outcome of the design and implementation of IP and its implications for curriculum transformation in higher education. To achieve this, we draw on Mezirow's (1990) theory of transformative learning to explain the multifaceted challenges through our own reflection as programme designers and facilitators, organisers and participants of curricular reviews using data from student interviews, student performance in first and subsequent years, and review documentation. Engaging in critical reflection means that teachers have to both understand their own experiences in the social context, and also understand how they can use that knowledge to develop their practice in the future. Our critical reflections on IP as a strategy for widening access has revealed the complexities of aligning intention with outcome that are significantly impacted by presuppositions that are epistemically flawed or socio-culturally insensitive. The added complexity is the number of stakeholders across four undergraduate education programmes that needed to be continually engaged and the small number of staff available for the IP design, implementation and evaluation, against the backdrop of everincreasing financial constraints. None of these challenges are unique to the department or faculty or university as evidenced in the media and coverage via 'The Conversation' of the past two years of student protest.

\section{REFERENCES}

Akooje, S. and M. Nkomo. 2007 Access and quality in South Africa higher education: The twin 
challenges of transformation. South African Journal of Higher Education 21(3): 385-399.

Amos, T. L. and S. Fischer. 1998. Understanding and responding to student learning difficulties within higher education context: A theoretical foundation for developing academic literacy. South African Journal of Higher Education 12(2): 17-23.

Amosun, S. L., N. Hartman V. J. van Rensburg, E. M. Duncan and E. Badenhorst. 2012. Processes in widening access to undergraduate Allied Health Sciences education in South Africa. African Journal of Health Professions Education 4(1): 34-39.

Angelil-Carter, S. (ed.) 1998. Access to success: Academic literacy in higher education. Cape Town: University of Cape Town.

Badenhorst, E. and R. Kapp. 2013. Negotiation of learning and identity among first-year medical students. Teaching in Higher Education. 10.1080/13562517.2012.753050.

Biggs, J. B. 1996. Enhancing teaching through constructive alignment. Higher Education 32: 1-18.

Boughey, C. and S. McKenna. 2016. Academic literacy and the decontextualized learner. Critical Studies in Teaching and Learning 4(2): 1-9.

Bowie, L. and V. Frith. 2006. Concerns about the South African Mathematical Literacy curriculum arising from experience of materials development. Pythagoras 64: 29-36.

Brinkworth, R., B. McCann, C. Matthews and K. Nordstrom. 2009. First year expectations and experiences: Student and teacher perceptions. Higher Education 58(2): 157-173.

Brookfield, S. 2003. Putting the critical back in critical pedagogy: A commentary on the path of dissent. Journal of Transformative Education 1: 141-149.

Brookfield, S. 2009. The concept of critical reflection: Promises and contradictions. European Journal of Social Work 12(3): 293-304.

Bush, T., R. Joubert, E. Kiggundu and J. van Rooyen. 2010. Managing teaching and learning in South African schools. International Journal of Educational Development 30: 162-168.

Bustillos, L. T. 2012. Re-thinking remedial education: The role of MSIs in serving under-prepared students in the 21st century. Rethinking Remedial Education. http://files.eric.ed.gov

Calkins, S. and A. Seidler. 2011. Faculty perceptions of relevance in teaching and learning. International Journal of Teaching and Learning in Higher Education 24(2): 215-225.

Crisp, G. T., E. J. Palmer, G. A. Turnbull, T. Nettelbeck, L. Ward, A. LeCouteur, A. Sarris, P. Strelan, and L. Schneider. 2009. First year student expectations: Results from a university wide survey. Journal of University Teaching and Practice 6(1): 11-26.

De Kadt, E. and N. Mathonsi. 2003. Writing in English with an 'African voice': Ownership, identity and learning. Journal for Language Teaching 37(1): 92-103.

Gunston, G. and L. Olckers. 2015. First year experience at Faulty of Health Sciences, University of Cape Town: Reflections on our experiences. Conference Paper presented at the SANRC FYE Conference Johannesburg. South Africa.

Hartman, N., H. Kathard, G. Perez, S. Reid, J. Irlam, G. Gunston, V. Janse van Rensburg, V. Burch, M. Duncan, D. Hellenberg, I. van Rooyen, M. Smouse, C. Sikakana, E. Badenhorst and B. Ige. 2012. Health Sciences undergraduate education at the University of Cape Town: A story of transformation. South African Medical Journal 102(6): 477-480.

Horstmanshof L. and C. Zimitat. 2003. Elaboration of the student self and persistence in higher education. In Educational Research: Risks and Dilemmas. NZARE/AARE Conference 29 November to 3 December. Auckland: New Zealand Association of Research in Education.

House, J. 2000. Understanding misunderstanding: A pragmatic-discourse approach to analyzing mismanaged rapport in talk across cultures. In Culturally speaking - Managing rapport through talk across cultures, ed. H. Spencer-Oatey, 146-164. London: Continuum.

Jackson, L., W. Meyer and J. Parkinson. 2006. A study of the writing tasks and reading assigned to undergraduate science students at a South African University. English for Specific Purposes 25(3): 
260-281.

Jansen, J. D. 1998. Curriculum reform in South Africa: a critical analysis of outcomes-based education. Cambridge Journal of Education 28(3): 321-331.

Kang'ethe, S. M. and P. Muhuro. 2014. Exploring hurdles associated with the orientation of freshmen in the institutions of higher learning: The case of two former black universities in South Africa. Mediterranean Journal of Social Sciences 5(23): 1242-1250.

Kember, D., A. Ho and C. Hong. 2008. The importance of establishing relevance in motivating student learning. Active Learning in Higher Education 9(3): 249-262.

Kinnear, A., M. Boyce, H. Sparrow, S. Middleton and M. Cullity. 2008. Diversity: A longitudinal study of how student diversity relates to resilience and successful progression in a new generation university. Perth, Australia: Australian Learning and Research Council.

Krause, K., R. Hartley, R. James and C. McInnis. 2005. The first year experience in Australian universities: Findings from a decade of national studies. Centre for the Study of Higher Education University of Melbourne.

Lantolf, J. P. 2000. Introducing Sociocultural Theory. In Sociocultural Theory of second language learning, ed. J. P. Lantolf, 1-26. Oxford: Oxford University Press.

Larrivee, B. 2000. Transforming teaching practice: Becoming the critically reflective teacher. Reflective Practice 1(3): 293-307.

Lave, J. and E. Wenger. 1991. Situated learning: Legitimate peripheral participation. Cambridge: Cambridge University Press.

Leijen, A., K. Valtna, D. A. J. Leijen and M. Pedaste. 2012. How to determine the quality of students' reflections? Studies in Higher Education 37(2): 203-217.

Luckett, K. 2010. Knowledge claims and code of legitimation: Implications for curriculum recontextualisation in South African higher education. Africanus 40(1): 4-18.

McInnis, C. 2001. Researching the first year experience: Where to from here? Higher Education Research and Development 20(2): 105-144.

McKenna, S. 2004. The intersection between academic literacies and student identities. South African Journal of Higher Education 18(3): 269-280.

Mezirow, J. A. 1990. Fostering critical reflection in adulthood: A guide to transformative and emancipatory learning. San Francisco, CA: Jossey-Bass.

Mezirow, J. A. 1995. Transformation theory of adult learning. In In defence of the lifeworld, ed. M. Welton. Albany, NY: State University of New York Press.

Mezirow, J. A. 1997. Transformative learning: Theory to practice. New Direction for Adult and Continuing Education 74: 5-12.

Mouton, N., G. P. Louw and D. L. Strydom. 2012, Historical analysis of the post-apartheid dispensation education in South Africa (1994-2011). International Business and Economics Research Journal 11(11): 1211-1222.

Muddiman, A. and A. B. Frymier. 2009. What is relevant? Student perceptions of relevance strategies in college classrooms. Communication Studies 60(2): 130-146.

Parker, S., P. Naylor and P. Warmington. 2005. Widening participation in higher education: What can we learn from the ideologies and practices of committed practitioners? Journal of Access Policy and Practice 2(2): 140-160.

Petersen, I., J. Louw and K. Dumont. 2009. Adjustment to university and academic performance among disadvantaged students in South Africa. Educational Psychology: An International Journal of Experimental Educational Psychology 29(1): 99-115.

Sikakana, C. N. T. 2010. Faculty and student support: Supporting student-doctors from under-resourced educational backgrounds: an academic development programme. Medical Education 44(9): 917925. 
Smit, R. 2012. Towards a clearer understanding of student disadvantage in higher education: Problematising deficit thinking. Higher Education Research and Development 31(3): 369-380.

Soudien, C. and J. Baxen. 1997. Transformation and outcome-based education in South Africa: Opportunities and challenges. Journal of Negro Education 66(4): 449-459.

Struyven, K., F. Dochy and S. Janssens. 2005 Students' perceptions about evaluation and assessment in higher education: A review. Assessment and Evaluation in Higher Education 30(4): 325-341.

Thomas L. 2010. Student retention in higher education: Role of institutional habitus. Journal of Education Policy 7(4): 423-442.

Tinto, V. 1975. Dropout from higher education: A theoretical synthesis of recent research. Review of Educational Research 45(1): 89-125.

Todd, A. and M. Mason. 2005. Enhancing learning in South African schools: Strategies beyond outcomes-based education. International Journal of Educational Development 25: 221-235.

Unterhalter, E. 2007. Global values and gender equality in education: Needs, rights and capabilities. In Gender education and equality in a global context: Conceptual frameworks and policy perspectives, ed. S. Fennell and M. Arnot, 19-34. London and New York: Routledge.

Van der Westhuizen, G. L. 2007. Evaluations of higher education transformation in South Africa. South African Journal of Higher Education 21(3): 552-569.

Voogt, J., H. Westbroek, A. Handelzalts, A. Walraven, S. McKenney, J. Pieters and B. de Vries. 2011. Teacher learning in collaborative curriculum design. Teacher and Teacher Education 27: 12351244

Vygotsky, L. S.1978. Interaction between learning and development. Translated by M. Lopez-Morillas. In Mind in society: The development of higher psychological processes, ed. M. Cole, V. JohnSteiner, S. Scribner and E. Souberman, 79-91. Cambridge, MA: Harvard University Press.

Watts, M. and D. Bridges. 2006. The value of non-participation in higher education. Journal of Education Policy 21(3): 267-290.

Wawrzynski, M. R., A. M. Heck and C. T. Remley. 2012. Student engagement in South African higher education. Journal of College Education Development 53(1): 106-123.

Warren, D. 2002. Curriculum design in a context of widening participation in higher education. Arts and Humanities in Higher Education 1(1): 85-99.

Wenger, E. 1998. Communities of practice. Learning as a social system. Systems Thinker. http://www.co-i-l.com/coil/knowledge-garden/cop/lss.shtml (accessed 30 December 2012.

Wilson, A. 2004. When contextualization cues mislead: Misunderstanding, mutual knowledge, and nonverbal gestures. California Linguistic Notes 29(1). http://hss.fullerton.edu/linguistics/CLN/ 04S\%20articles/wilson-ambiv-nvc.pdf

Wilson, D. and D. Sperber. 1985. On choosing the context for utterance interpretation. In Foregrounding Background, (Doxa), ed. J. Allwood and E. Hjemquist, 51-64.

Wilson-Strydom, M. 2011. University access for social justice: a capabilities perspective. South African Journal of Education 31(3): 407-418.

Yorke, M. and B. Longden. 2008. The first-year experience of higher education in the UK. The Higher Education Academy. http://www.heacademy.ac.uk/assets/York/documents/resources/ publications/FYEFinalReport.pdf (accessed 3 November 2010). 